\title{
GEOPROCESSAMENTO APLICADO AO ESTUDO DO IMPACTO AMBIENTAL DA MINERAÇÃO E PLANEJAMENTO DE RECUPERAÇÃO NA MINA DO PERAU, ADRIANÓPOLIS, PR
}

\author{
A.B.Macedo ${ }^{1}$ \\ F.A.F.Salles ${ }^{1}$ \\ S.V.Liotte ${ }^{1}$ \\ M.Guimarães ${ }^{2}$
}

Os rios da bacia do Ribeira apresentam poluição por metais pesados derivados da mineração, que se reflete nos teores em sedimentos, água e seres vivos. O Ribeirão Grande drena áreas com minas de chumbo, em atividade (Canoas) e paralisadas (Perau e Barrinha). 0 controle ambiental da mineração é precário, nada sendo feito para recuperar as áreas das minas e trabalhos de pesquisa antigos. Mones de rejeitos e de minério de baixo teor, áreas desmatadas sujeitas a erosão e drenagem de galerias abandonadas contribuem para a poluição.

Macedo (1992) efetuou levantamento geoquímico, com amostragem de sedimentos de corrente nos ribeirões do Perau e Grande, com abertura das amostras por ácido nítrico a quente e análise por absorção atômica para $\mathrm{Cu}, \mathrm{Pb}, \mathrm{Zn}, \mathrm{Fe}$ e $\mathrm{Mn}$.

Foram encontrados teores superiores a 20.000 ppm de $\mathrm{Pb}$ na fração de 80-150 \# a até $1,5 \mathrm{~km}$ abaixo da mina do Perau, nos ribeirões do Perau e Grande. Os teores diminuem até a faixa de 100 ppm de $\mathrm{Pb}$ a $17 \mathrm{~km}$ abaixo da mina e têm pequeno aumento (até 292 ppm na fração < 150) \# devido à contribuição de sedimentos vindos do ribeirão das Canoas, que drena a mina do mesmo nome. Novamente há abaixamento dos teores, aumentando estes na chegada do Ribeirão do Laranjal, que drena a mina da Barrinha e trabalhos de pesquisa próximos. Os sedimentos desta drenagem têm até $36000 \mathrm{ppm}$ de $\mathrm{Pb}$ na fração < 150 \#. Os teores de $\mathrm{Cu}$ e $\mathrm{Zn}$, embora de menor valor, também refletem claramente a poluição pelas três áreas de mineração. Os teores de $\mathrm{Cu}, \mathrm{Pb}$ e $\mathrm{Zn}$ são muito superiores aos encontrados em áreas análogas sem mineração, da mesma região, mesmo naquelas onde ocorrem anomalias associadas a mineralizações. São muito maiores que os limites máximos admissíveis para manutenção da vida aquática. Os altos teores em sedimentos são concordantes com os encontrados em outras minas da região (Rocha, Furnas), e se refletem na água e nos organismos aquáticos.

\footnotetext{
${ }^{1}$ Departamento de Geologia Econômica e Geofísica Aplicada, Instituto de Geociências, USP.

${ }^{2}$ Instituto de Biociências, USP.
} 
Devido à importância da poluição detectada foi iniciado um estudo para determinação das fontes de poluição e elaboração de propostas para seu controle e para recuperação das áreas degradadas pela mineração. A primeira fase deste estudo concentra-se na mina do Perau, escolhida por reunir um grande conjunto de informações e por ser a primeira fonte importante de poluição na bacia do Ribeirão Grande.

A mina do Peray situa-se no município de Adrianópolis, Paraná, tendo o depósito forma lenticular, natureza stratabound, e três niveis mineralizados, com $\mathrm{Cu}, \mathrm{Pb}$ e barita predominando em cada nivel. A camada mineralizada com metais básicos apresenta dimensões de aproximadamente $1000 \times 400 \mathrm{~m}$, com espessura máxima de $14 \mathrm{~m}$ (zona oxidada) e média de $3 \mathrm{~m}$. Suas reservas totalizam cerca de 2 milhões de toneladas, com teores médios ao redor de $5 \% \mathrm{~Pb}, 2 \% \mathrm{Zn}$ e $100 \mathrm{~g} / \mathrm{t} \mathrm{de} \mathrm{Ag.} \mathrm{Os}$ solos são frágeis, litossolos ou cambissolos, com alta erosão e movimentação lateral, condicionados pela grande declividade. A mina foi lavrada de 1976 a 1986 estando atualmente paralisada. Os principais problemas ambientais são: montes de rejeitos e minérios de baixo teor, que quando são erodidos liberam sedimentos com metais pesados; as águas de drenagem das galerias, e as áreas desmatadas e escavadas, que sofrem erosão e liberam sedimentos, às vezes com metais pesados. A área é uma das melhor estudadas no vale do Ribeira, com sínteses em Batolla et al. (1981), MMAJ/DNPM (1981-1984) e Macedo (1987).

Está sendo montado um Sistema de Informações Georeferenciadas (SIG), reunindo informações geológicas, geoquímicas, topográficas, de vegetação, de edificações e atividades de mineração e de fontes de poluição. A primeira parte desta fase foi efetuada como trabalho curricular da disciplina "Mineração e Meio Ambiente", ministrada pelo primeiro autor, tendo sido digitalizados mapas topográficos, de vegetação, geológico e de atividades mineiras e foi elaborado um Modelo Numérico de Terreno (MNT). O trabalho continua como atividade de teste de tecnologia e iniciação científica. Novos mapas e informações estão sendo digitalizados e está sendo efetuada análise para determinação dos processos de controle de poluição e atividades de recuperação adequadas à área. O sistema utilizado é o IDRISI (Clark University), que reúne baixo custo, facilidade de operação e treinamento e capacidade suficiente para os trabalhos de digitalização e análise. As ilustrações e mapas finais estão sendo elaborados com os programas Paintbrush e Photostyler.

\section{REFERÊNCIAS BIBLIOGRÁFICAS}

Batolla Jr. et al. (Coordenador) (1981) Projeto Integração e Detalhe Geológico no Vale do Ribeira. São Paulo, DNPM/CPRM, 15 v.

Macedo, A.B. (1992) Mining pollution in the Ribeira river valley, Southern Brazil. Abstracts for the Conference on Hazardous Waste Research. Boulder, Colorado, p.19-20.

Macedo, A.B., (1987) Prospeç̧ão Litogeoquímica na Mina do Perau, Paraná. São Paulo, Instituto de Geociências, USP, 180p. (tese de doutoramento).

MMAJ - DNPM, 1981 a 1984 - Report on Geological Survey of Anta Gorda, Brasil. Phases I to IV. Tokio, MMAJ-DNPM/JICA-CPRM-IPT, $5 \mathrm{v}$. 